\title{
A STUDY ON THE MAST CELLS DENSITY IN THE WHOLE WALL OF INTRAPULMONARY BRONCHI AND BRONCHIOLES IN RATS OF DIFFERENT AGE USING TOLUIDINE BLUE STAINING
}

\author{
I. Ivanova* \\ Department of Anatomy, Medical Faculty, Trakia University, Stara Zagora, Bulgaria
}

\begin{abstract}
The contentious information concerning mast cells distribution in intrapulmonary airways in normal rat lung gave us a reason to perform this study. The aim of our study is to present the mast cells density in the whole wall of large-, small bronchi and bronchioles in rats of three different age groups in terms of the clinical significance.

Mature and immature male Wistar rats were used. Sections from both left and right lung were stained with Toluidine blue. Distribution of mast cells was specified for the whole wall of intrapulmonary large-, small bronchi and bronchioles. The number of mast cells per airways` wall was compared between pulmonary lobes and different age groups.

In conclusion, the topographic and age dependent differences in mast cell distribution found in this study implement the information about mast cell localization and help to elucidate the role of these cells in maintaining of lung homeostasis as well as the data can be used as referent values.
\end{abstract}

Key words: mast cells, rat, lung, intrapulmonary airways

\begin{abstract}
ABBREVIATIONS
LL, left lung; CrLRL, cranial lobe of right lung; CaLRL, caudal lobe of right lung; MCs, mast cells; $\mathbf{L B r}$, large bronchi; SBr, small bronchi; Tbol, terminal bronchioles; RBol, respiratory bronchioles; MMC, mucosal mast cells; CTMC, connective tissue mast cells.
\end{abstract}

\section{INTRODUCTION}

It is known that mast cells (MCs) take a main part in allergic and hypersensitivity reactions, but they are also involved in a variety of chronic inflammatory processes such as parasitic infections $(1,2)$, neoplasia (3) and pulmonary diseases $(4,5)$. It is also proved that MCs play a central role in the pathogenesis of fibrotic lung diseases. Encreased numbers of MCs are found in the lungs of patients with sarcoidosis (6), hypersensitivity pneumonitis (7), silicosis (8) and idiopathic pulmonary fibrosis (IPF) (9). The inflammatory response includes different types of cells - macrophages,

\footnotetext{
*Correspondence to: Ivelina Gancheva Ivanova, Department of Anatomy, Faculty of Medicine 11 Armejska, Stara Zagora 6000, Bulgaria, e-mail: ivcho_84@abv.bg
}

neutrophils, lymphocytes, and mast cells. initiate the pulmonary fibrosis process. Two mast cell mediators are identified as fibrogenic: histamine and renin, via angiotensin(ANG II) (11). Both human and rat lung fibroblasts express receptors for these mediators and when activated, they start proliferation and collagen synthesis (12). Recently, Stefanov et al. (13) observed the expression by mast cell granules in rat stomach. Ghrelin is a peptide hormone synthesized by endocrine cells in gastrointestinal tract of rats and humans (14, 15) but rarely occurs in extrahepatic biliary tract (16). Its role in appetite regulation, control of energy homeostasis, gastrointestinal contraction and secretion is well known (14, 17).

There is a controversial information concerning mast cells distribution in intrapulmonary airways in normal rat lung. According to some authors, in the rat, there is a reduction in mast cell number from large to small bronchi (18-20). For the first time, the 
distribution of mast cells in different layers of the intrapulmonary airways in rats was established by Ivanova et al., using toluidine blue staining and immunohistochemical staining to visualize serotonin-positive mast cells (21).

\section{MATERIAL AND METHODS}

\section{Animals}

Eighteen male Wistar rats (six rats of each age group) at the age of 20 days, 3 months and 1 year were used in our study. The procedures were performed according to the Scientific Project (№13/2017) of Medical Faculty of Trakia University, StaraZagora, Bulgaria.

The cranial and caudal lobes of right lung as well as cranial part of left lung from each animal were removed, then immersed in the same fixative for $24 \mathrm{~h}$, washed in PBS, dehydrated, cleared in xylene and embedded in paraffin.

Histochemistry for detection of metachromatic mast cells using toluidine blue

Cross sections of $5 \mu \mathrm{m}$ thickness from the tissue specimens were cut and mounted on gelatin-coated glass slides, deparaffinised in two changes of xylene, and rehydrated through descending ethanol concentrations. The sections were immersed in buffered solution of toluidine blue $(\mathrm{pH}=3)$.

\section{Statistical analysis}

The number of mast cells was estimated on two microscopic fields (X200 with area of $0.163 \mathrm{~mm}^{2}$ ) from the sections of the three lung lobes from each animal using a light microscope (LEIKA DM1000) equipped with a digital camera (LEIKA DFC 290). The data for mast cells density (number per field) were processed by GraphPad Prism 6 for Windows (GraphPad Software, Inc., USA) via one-way analisys of variance (one-way ANOVA) followed by Tukey-Kramer's post-hoc test. Pvalues of less than 0.05 were considered statistically significant. The data are presented as mean $\pm \mathrm{SD}$.

\section{RESULTS}

In this study we used toluidine blue staining to mark and count metachromatic MCs in the different layers of the wall of intrapulmonary airways in the left lung (LL), cranial (CrLRL) and caudal lobes of right lung (CaLRL) in rats at different ages.

Mast cells were counted in the airways propria bordered by the base of the epithelium and muscular layer, also in the muscular and adventitial layer. In general, mast cells were located in lamina propria predominantly of large (Figure 1) and small bronchi (Figure 2), but rarely in propria of bronchioles (Figure 3), near blood vessels in the adventitia. The most MCs were found in the adventitial and muscle layers of the airways, than in the propria. The lowest number of MCs was found in the respiratory bronchioles.

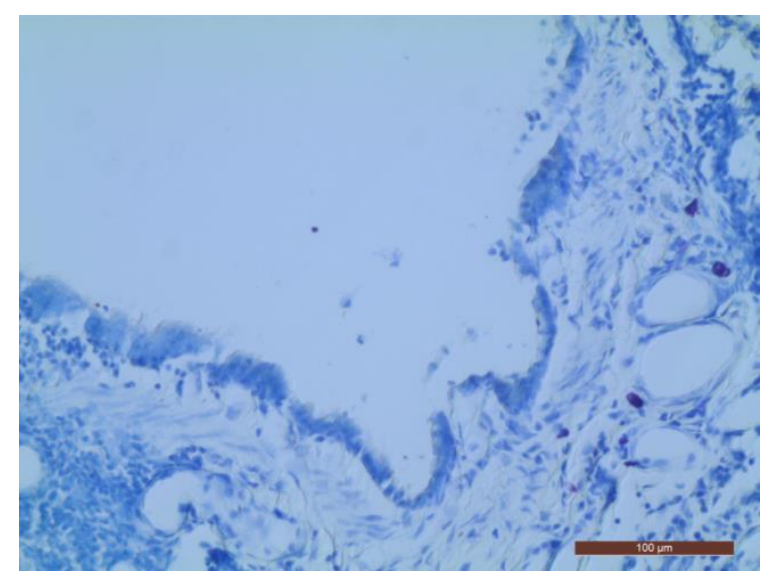

Figure 1. Mast cells localization in the wall of large bronch.

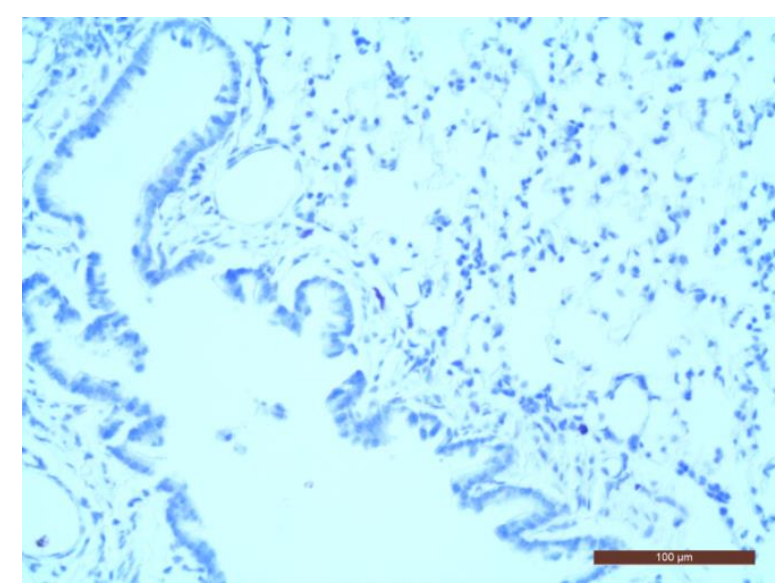

Figure 2. Mast cells localization in the wall of small bronch.

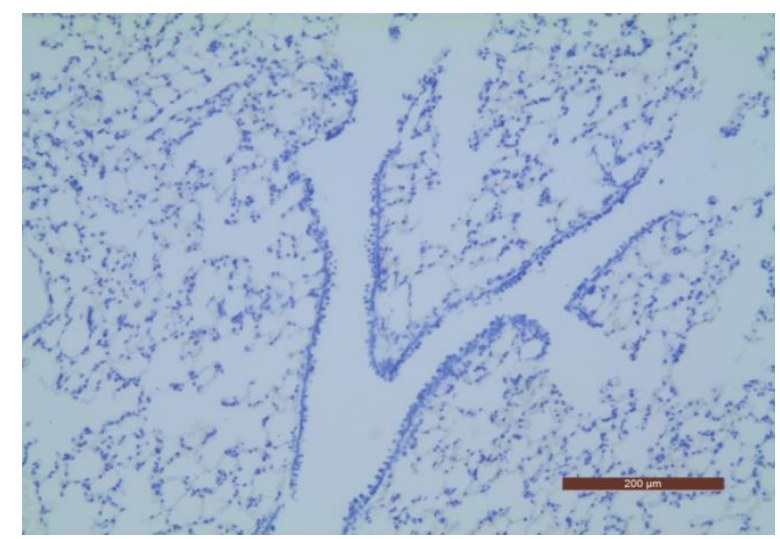

Figure 3. Mast cells are absent in the wall of terminal and respiratory bronchioles. 
We found differences in the distribution of lung MCs according to both: the location - left lung or cranial and caudal lobes of right lung, and the age of animals.

\section{MC number in the whole wall of large bronchi (LBr)}

In the cranial right lung lobe $\mathrm{MC}$ number was the highest in the large bronchi`s wall in the

\section{IAVANOVA I.}

20-day-old, followed by 3-month- and 1-yearold rats. In the right caudal lobe, the highest MC number was established in 3-month-old, followed by 20 -day- and 1-year-old rats. In the left lobe the most MC were detected at the age of 20 days, followed by the age of 3 months and the age of 1 year (Figure 4a).

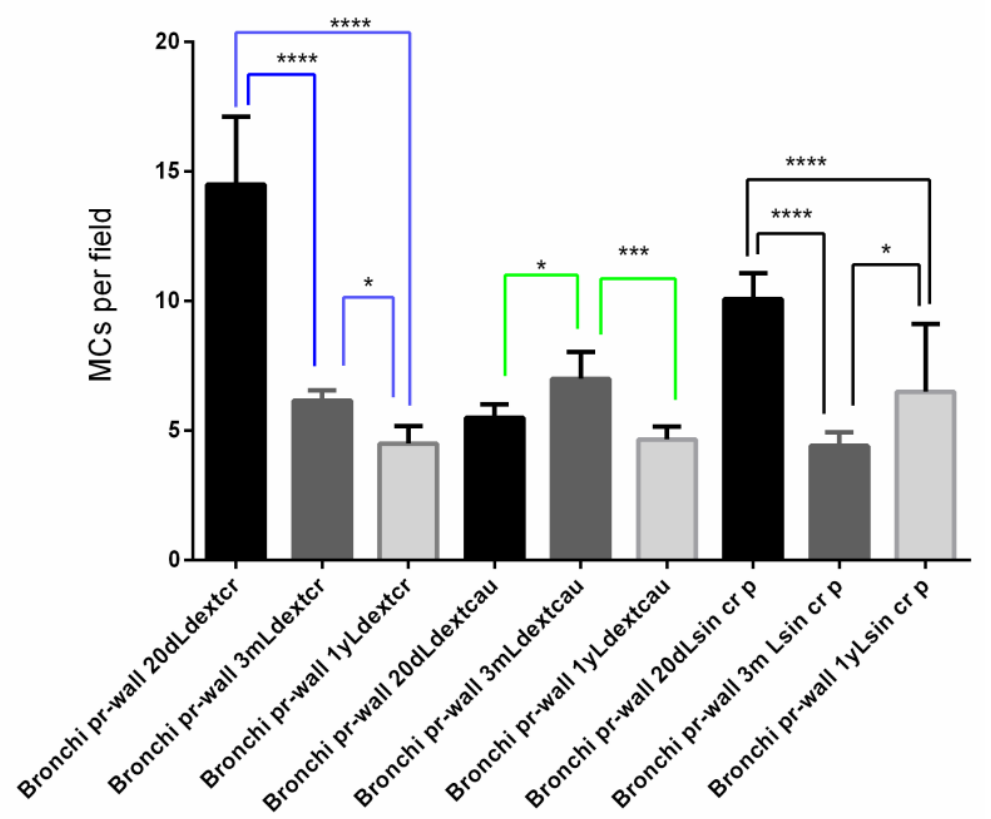

Figure 4a. MC number in the whole wall of large bronchi ( $\mathrm{LBr})$.

When comparing the mast cell number in different lobes for each age we found that the highest MC number in rats at the age of 20 days was in cranial lobe, followed by left lung and caudal right ones, respectively; at the age of 3 months - in caudal and cranial lobe of right lung, and left lung respectively; at the age of 1 year - in cranial lobe, left lung and caudal lobes of right lung, respectively (Figure 4b).

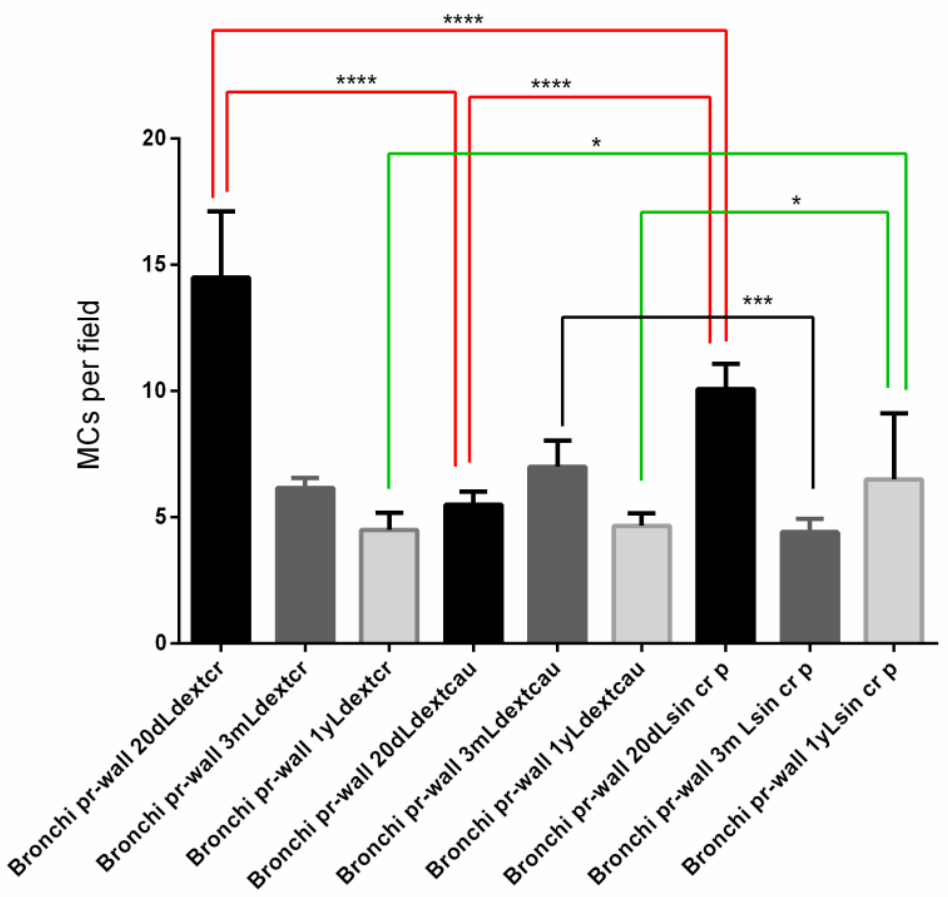

Figure 4b. MC number in the whole wall of large bronchi ( $\mathrm{LBr})$. 
MC number in the whole wall of small bronchi $(\mathrm{SBr})$

$\mathrm{MC}$ number in the wall of $\mathrm{SBr}$ in left lung and in the two lobes of right lung in the rats of these three age groups, was detected. In the cranial lobe of right lung and left lung, MC number was the highest in the wall of $\mathrm{SBr}$ in
IAVANOVA I.

the 3-month- and 1-year-old animals showing the same values, followed by 20 -day-old rats. In the caudal lobe, the highest $\mathrm{MC}$ number was also in the 3-month- and 1-year-old-animals; however MCs in 20-day-old rats were not found (Figure 5a).

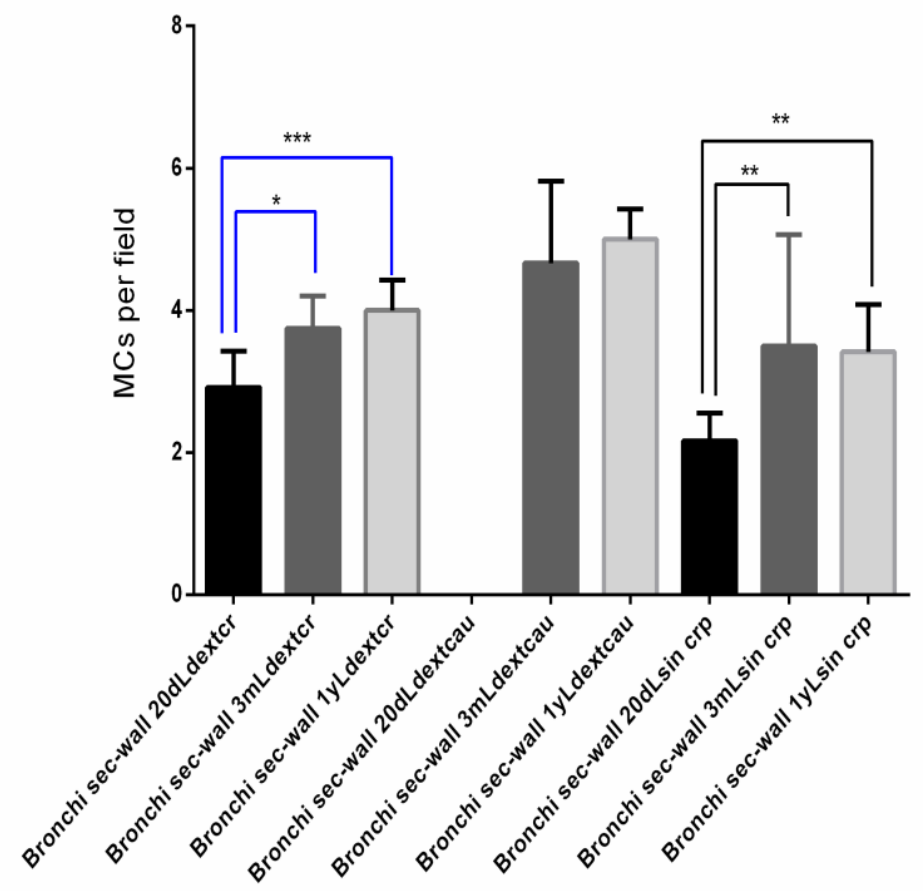

Figure 5a. $\mathrm{MC}$ number in the whole wall of small bronchi $(\mathrm{SBr})$.

When comparing the mast cell number in different lobes for each age we found that in rats at the age of 20 days, the MC number in cranial right lobe and left lung was similar, but in caudal one these cells were missing; at the age of 3 months - in caudal lobe, cranial lobes and left lung, respectively; at the age of 1 year - in caudal, cranial lobe and left lung, respectively (Figure 5b).

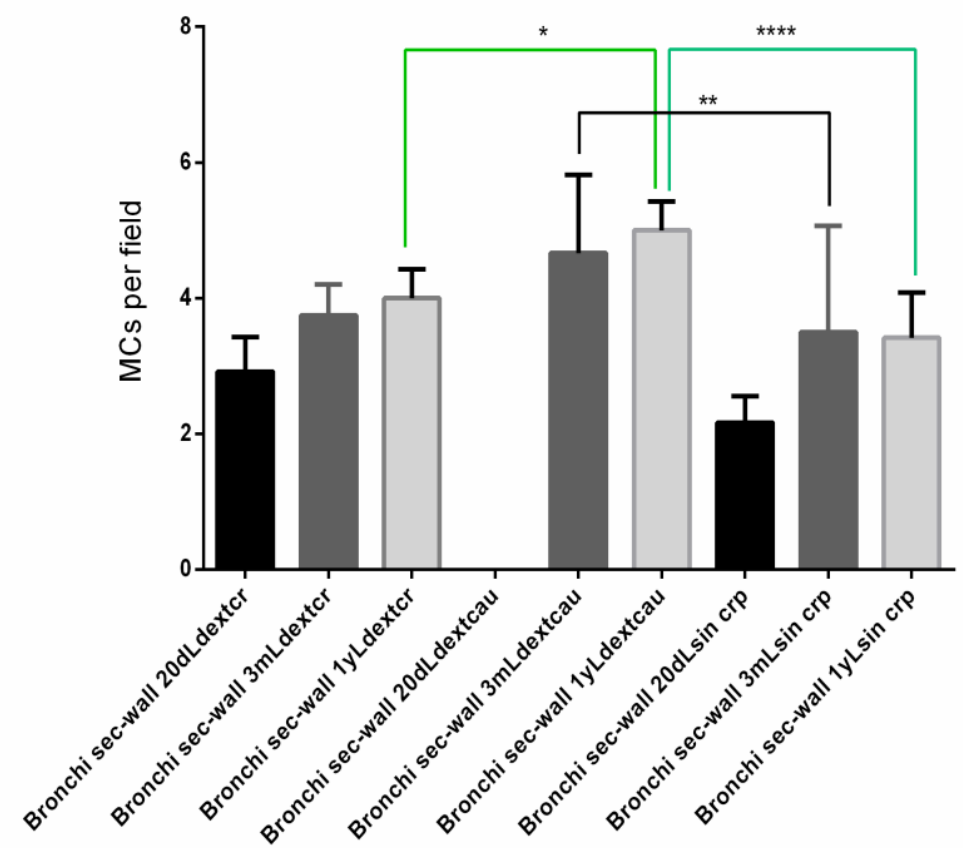

Figure 5b. MC number in the whole wall of small bronchi (SBr). 
MC number in the whole wall of terminal bronchioles (Tbol)

MC number in the wall of Tbol in the studied right and left lung was detected. In the cranial lobe, MCs were observed only in 1-year-old animals, but in caudal right lobes - in 3-
IAVANOVA I.

month-old rats only. In the right caudal lobe, the highest MC number was in the 3-monthold rats followed by 1-year-old animals, however MCs in 20-day-old rats were not found (Figure 6a).

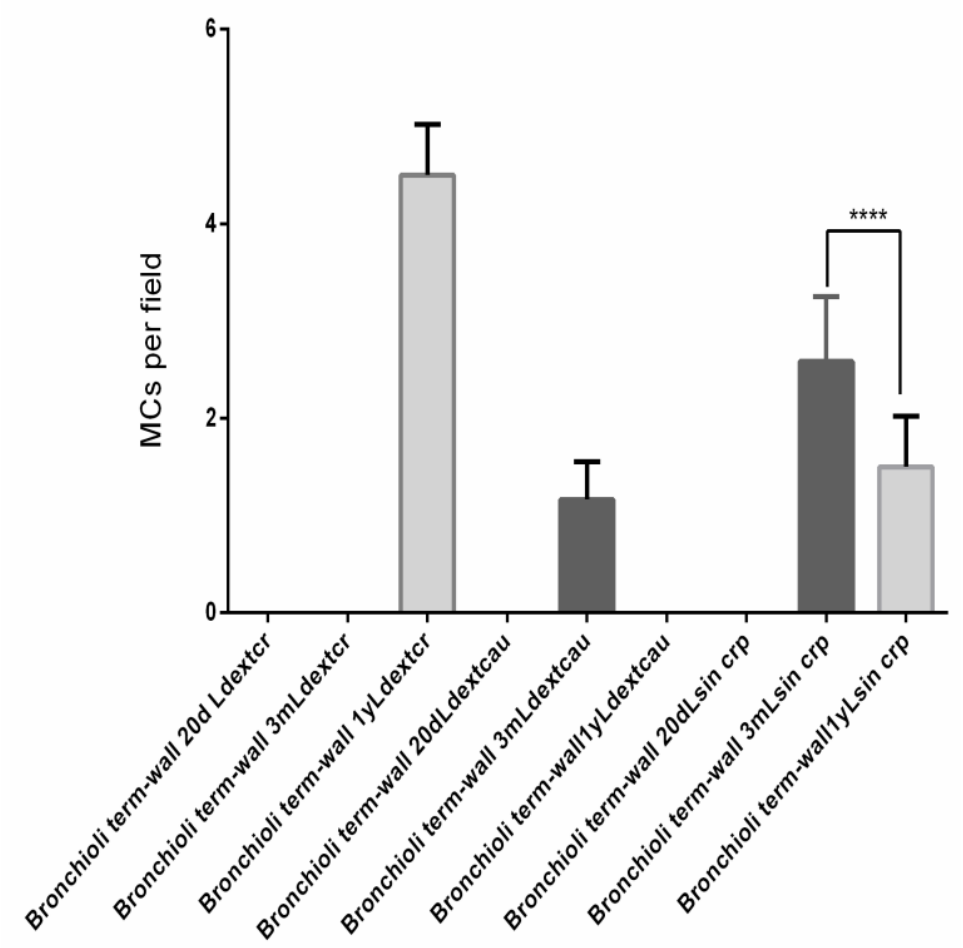

Figure 6a. MC number in the whole wall of terminal bronchioles (Tbol).

When comparing the mast cell number in different lobes for each age we found that in the three lung lobes of rats at the age of 20 days, MC were missing; at the age of 3 months - MC number in the left lobe was higher than in the right caudal lobe, but in cranial right lobe MCs were missing; at the age of 1 year MCs were most abundant in the right cranial lobe than in the left lobe, but were missing in the caudal right lobe (Figure 6b).

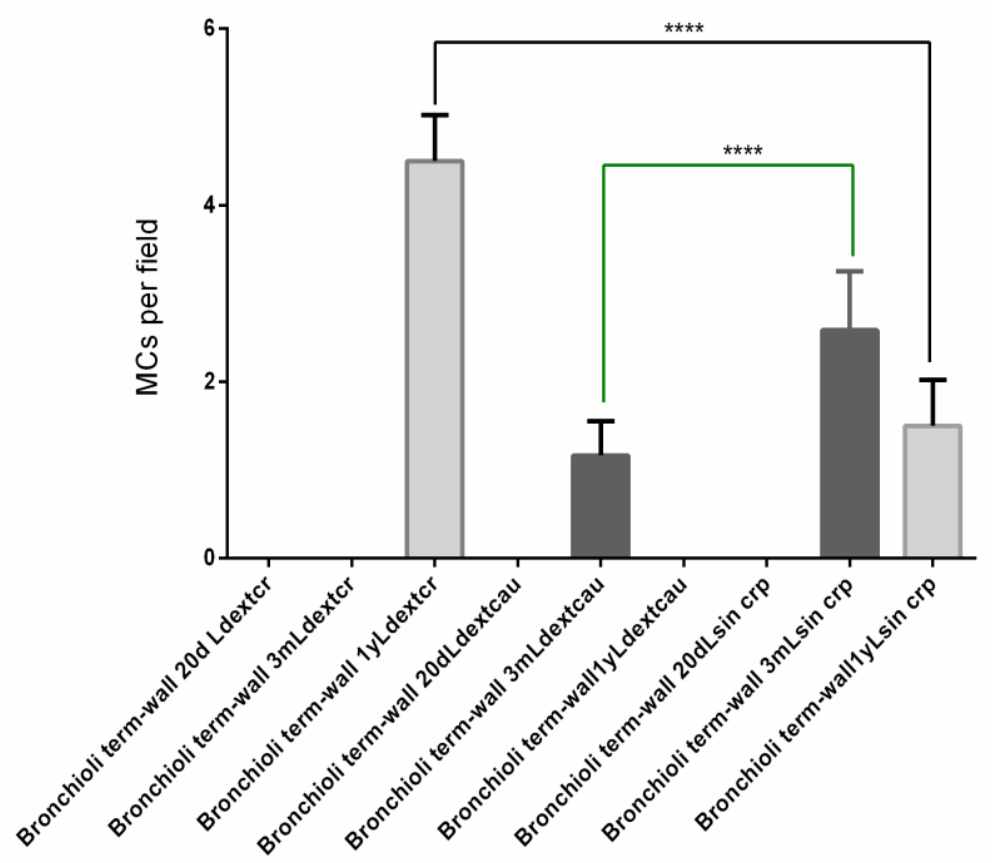

Figure 6b. MC number in the whole wall of terminal bronchioles (Tbol). 
MC number in the whole wall of respiratory bronchioles (RBol)

MCs were presented in the muscle layer of $\mathrm{RBol}$ in the cranial right and left lobes in rats at the age of 1 year only. Their number in the
IAVANOVA I.

cranial right lobe was higher than in the left one. MCs were missing in propria of all studied lung lobes in rats of other two ages (Figure 7).

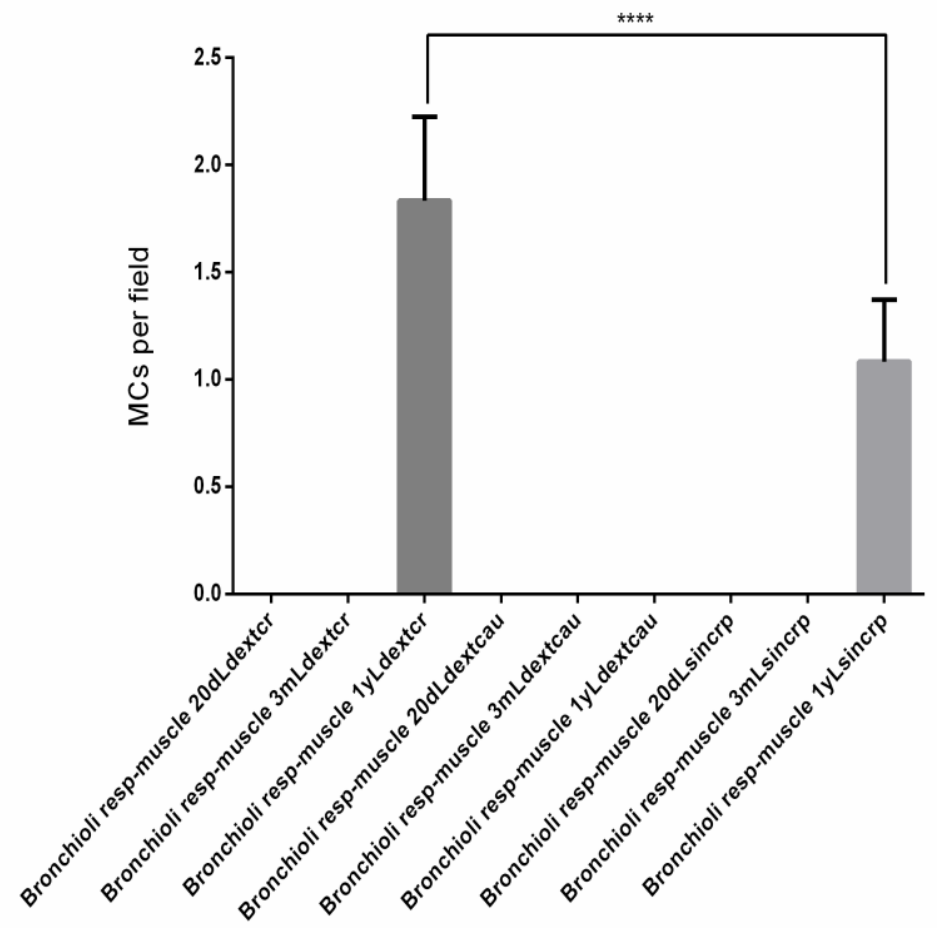

Figure 7. MC number in the whole wall of respiratory bronchioles (RBol).

\section{DISCUSSION}

In our study we identified the distribution of mast cells in the whole wall of intrapulmonary large-, small bronchi and bronchioles in three aged groups - 20 days, 3 months and 1 year old rats. We used toluidine blue staining, at low $\mathrm{pH}$, which allows to visualised glycosaminoglycans, produced by both types of mast cells- mucosal and connective tissue mast cells (22). Toluidine blue staining is used to mark mast cells in various animal species (23-28). At birth both types of mast cells- mucosal (MMC) and connective tissue mast cells (CTMC) are represented in very low numbers in rat' $\mathrm{s}$ respiratory tract (29). Our study confirms the results of Wilkes et al. about the increase of mast cell number with age. MMC are the main phenotype in the epithelium and lamina propria of the lung airways in different age groups. CTMC predominated in the submucosal layer of the airways as well as in the lung parenchyma (29).

The role of mast cells in the bronchial wall can be explained by studies of Ivanova et al. (21) about serotonin and of Lundequist \& Pejler (30) about histamine, released from the mast cells. These cells possess a double effect on smooth muscle cells - they regulate smooth muscle cell contraction in the wall of bronchi and bronchioles and they also mediate the smooth muscle cell relaxation of the same structures $(17,21)$. Various effects of histamine include vasodilation, bronchospasm, increased capillary permeability, and smooth muscle contraction. All these effects are associated with allergic and inflammatory reactions (30).

\section{CONCLUSION}

Mast cell populations in the left and right lung of the normal rats are different in terms of both indicators- their distribution along the bronchial tree (from larger to smaller diameters) and their distribution in different age groups. The topographic and age dependent differences in mast cell distribution found in this study implement the information about mast cell localisation and help to elucidate the role of these cells in maintaining of lung homeostasis as well as the data can be used as referent values.

\section{ACKNOWLEDGMENTS}

I would like to thank to scientific project number 13/2017, Medical Faculty, Trakia University, Stara Zagora, for delivering of animals for this study. 


\section{REFERENCES}

1. Miller, H.R.P. and Jarret, W.F.H., Immune reactions in mucous membranes. Intestinal mast cell responses during helminth expulsion in the rat. Immunology, 20:277, 1971.

2. Befus, A.D. and Bienenstock, J., Immunologically-mediated intestinal mastocytosis in Nippostrong/lus brasiliensis infected rats. Immunology, 38:95, 1979.

3. Hartveit, F., Mast cells and metachromasia in human breast cancer: their occurrence, significance and consequence: a preliminary report. J. Pathol., 134:7, 1981.

4. Kawanami, O., Ferrans, V.J., Fulmer, J.D. and Crystal, R.G., Ultra-structure of pulmonary mast cells in patients with fibrotic lung disorders. Lab. Invest., 40:717, 1979.

5. Haslam, P.L., Cromwell, O., Dewar, A. And Turner-Warwick, M., Evidence of increasedhistamine levels in lung lavage fluids from patients withcryptogenicfibrosingalveolitis. Clin. exp. Immunol. 44: 587, 1981.

6. Ohrn, M.B, Sköld, C.M., VanHageHamsten, M., Sigurdardottir, O., Zetterström, O., Eklund, A., Sarcoidosis patients have bronchial hyperreactivity and signs of mast cell activation in their bronchoalveolar lavage. Respiration, 62:136-142, 1995.

7. Schildge, J., Klar, B., Hardung-Backes, M., Mast cells in bronchoalveolar lavage fluid of patients with interstitial lung diseases. German Pneumologie, 57:202-207, 2003.

8. Hamada, H., Vallyathan, V., Cool, C.D., Barker, E., Inoue, Y., Newman, L.S., Mast cell basic fibroblast growth factor in silicosis. Am J RespirCrit Care Med, 161:2026-2034, 2000.

9. Cha, S.I., Chang, C.S., Kim, E.K., Lee, J.W., Matthay, M.A., Golden, J.A.,Elicker, B.M., Jones. K., Collard, H.R., Wolters, P.J., Lung mast cell density defines a subpopulation of patients with idiopathic pulmonary fibrosis. Histopathology, 61:98106, 2012.

10.Andersson, C.K., Andersson-Sjöland, A., Mori, M., Hallgren, O., Pardo-Aeriksson, L., Bjermer, L., Löfdahl, C.G., Selman, M., Westergren-Thorsson, G., Erjefält, J.S., Activated MCTC mast cells in filtrate diseased lung areas in cystic fibrosis and idiopathic pulmonary fibrosis. RespirRes, 12:139, 2012.

11.Kawatani, K., Kondo, M., Tamaoki, J., Tagaya, E., Nagai, A., The clinical significance of mast cell tryptase in bronchial alveolar lavage fluid in interstitial lung diseases. Japanese Nihon Kokyuki Gakkai Zasshi, 45:848-855, 2007.

12.McLarty, J.L., Meléndez, G.C., Brower, G.L., Janicki, J.S., Levick, S.P., Tryptase/Protease-activated receptor 2 interactions induce selective mitogenactivated protein kinase signaling and collagen synthesis by cardiac fibroblasts. Hypertension, 58:264-270, 2011.

13.Stefanov, I. S., Ananiev, J.R., Ivanova, K.V., Tolekova, A.N., Vodenicharov, A.P. and Gulubova, M.V., Distribution of ghrelin-positive mast cells in rat stomach. Biotechnology \& Biotechnological Equipment, 31(4):774-781, 2017.

14.Date, Y., Kojima, M., Hosoda, H., Sawaguchi, A., Mondal, M.S., Suganuma, T., Matsukura, S., Kangawa, K. and Nakazato, M., Ghrelin, a novel growth hormone-releasing acylated peptide, is synthesized in a distinct endocrine cell type in the gastrointestinal tracts of rats and humans. Endocrinology, 141-142, 2000.

15.Hamza, S., Valkova, I., Atanasova, P., Gulubova, M., Localization of ghrelin in the epithelial cells of the duodenum in the rat. Trakia Journal of Sciences, 13(2):1-3, 2015.

16.Vulkova, I., Hamza, S., Gulubova, M., Sivrev, D., Characteristics of ghrelin positive cells in extrahepatic bile ducts of the rat. Trakia Journal of Sciences, 12(1):144-146, 2014.

17.Penkova, N., Atanasova, P., Zheleva, Z., Chilikova, M., Ghrelin and its Role in the Secretion and Motility of the Gastrointestinal Tract in Humans. IOSR Journal of Dental and Medical Sciences (IOSR-JDMS), 15(12ver5):107-113, $2016 \mathrm{~b}$.

18.Ahlstedt, S., Smedegard, G., Nygren, H., Bjorksten, B., Immune responses in rats senitized with aerosolized antigen. Int. Archs Allergy Appl. Immun., 72:71-78, 1983.

19.Bachelet, C. M., Bernaudin, J.F., FleuryFeith, J., Distribution and histochemical characterization of pulmonary mast cells in the rat and guinea pig. Int Arch Allergy Appl. Immun., 87:225-229, 1983.

20.Goto, T., Befus, D., Low, R., Bienenstock, $\mathrm{J}$., Mast cell heterogeneity and hyperplasia in bleomycin-induced pulmonary fibrosis of rats. Am. Rev. Resp. Dis., 130:797-802, 1984.

21.Ivanova, I., Tomov, N., Dimitrov, N., Atanasova, D., Sivrev, D., Stefanov, I., 
Distribution of serotonin positive mast cells in the intrapulmonary airways of rats. Comptes rendus de l'Académie bulgare des sciences: sciences mathématiques et naturelles, 72(2):244-249, 2019.

22.Enerback, L., Kolset, S.O., Kusche, M., Hjerpe, A., Lindahl, U., Glycosaminoglycans in rat mucosal mast cells. J. Biochem., 227:661-668, 1985.

23.Stefanov, I.S. and Vodenicharov, A.P., Morphological study of mast cells in feline paranal sinus. Bulgarian Journal of Veterinary Medicine, 11(2):121 - 124, 2008.

24.Stefanov, I.S., Histochemical investigation of the mast cells in the paranal sinus (Sinus paranalis) of the sexually mature dogs. Bulgarian Journal of Veterinary Medicine, 12(1):19-23, 2009.

25.Stefanov, I. S. and Vodenicharov, A.P., Tyrosine hydroxylase expression in the mast cells and autonomic nerves in the porcine common hepatic duct. Comptes rendus de l'Acad'emie bulgare des Sciences Tome 69, 8, 2016.
IAVANOVA I.

26.Stefanov, I. S., Vodenicharov, A.P., Tsandev, N.S. and Sevrieva, D., Histochemical study of heparin-positive mast cells in the terminal part of porcine ductus choledochus and papilla duodeni major. Anatomia, Histologia, Embryologia, 45, 5, 386-39, 2016.

27.Tomov, N., Dimitrov, N., Modified Bismarck brown staining for demonstration of soft tissue mast cells. Trakia Journal of Sciences, 3:195-197, 2017.

28.Pirovski, N., Staykova-Pirovska, Y., Atanasova, D., Dimitrov, N., Mast cell reaction to acupuncture on tongue. Trakia Journal of Sciences, 3:199-202, 2019.

29.Wilkes, L.K., McMenamin, C., Holt, P.G., Postnatal maturation of mast cell subpopulations

30.in the rat respiratory tract. Immunology, 75(3):535-541, 1992.

31.Lundequist, A., Pejler, G., Biological implications of preformed mast cell mediators. Cell Mol Life Sci, 68:965-975, 2011. 